\title{
Target Spot of Tomato in Florida ${ }^{1}$
}

\section{Keevan MacKenzie, Jessica Chitwood, Gary Vallad, and Sam Hutton ${ }^{2}$}

Target spot of tomato, caused by Corynespora cassiicola, was first reported in Florida in 1972. In the last few decades it has become one of the most destructive foliar and fruit diseases of tomato in the state (MacKenzie et al. 2018). This pathogen is commonly found in the tropics, the subtropics, and greenhouse production around the world. In the United States, distribution is largely confined to Florida, where the environment favors disease development. This pathogen also infects cucumber, blueberry, papaya, cotton, and sesame in Florida (Blasquez 1967; Onofre 2016; McMillan 1986). It is very adaptable, infecting well over 500 species of plants (Dixon 2009).

In Florida, fresh-market tomatoes bring in $\$ 400-\$ 500$ million annually as the third most valuable crop in the state (NASS 2018). Defoliation and fruit damage from target spot can have serious economic implications for growers.

\section{Symptoms}

Lesions can form on the roots, stems, and leaves of the plant, but most importantly on the fruits. Leaf lesions are initially dark brown and pinpoint, appearing nearly identical to early bacterial spot symptoms caused by Xanthomonas spp. However, as target spot lesions enlarge, the centers become light brown to gray with dark outer concentric rings sometimes surrounded by a diffuse yellowing (chlorosis) (Figure 1). These symptoms are easily confused with those of early blight, caused by Alternaria spp., or those of gray leaf spot, caused by Stemphyllium spp.

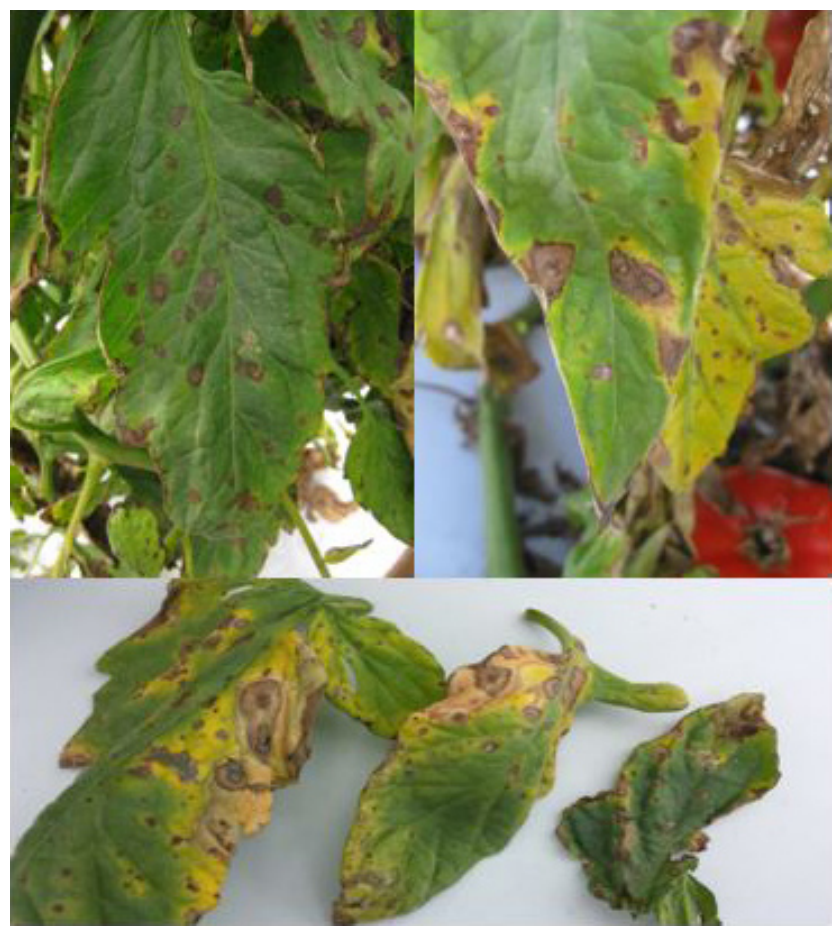

Figure 1. Tomato leaves exhibiting symptoms of target spot caused by Corynespora cassiicola. Note the variability in foliar symptoms attributed to differences in tomato variety, leaf age, and C. cassiicola isolate.

Credits: G. Vallad (top); K. MacKenzie (bottom).

Leaf lesions can develop quickly and coalesce, causing blighting and premature defoliation (Figure 2). Leaf petiole and stem lesions are typically dark brown and oval-shaped (Figure 3). Fruit lesions start as small, brown, sunken flecks (Figure 4). Those flecks expand into deeply pitted lesions that rapidly develop during ripening. They often leave

1. This document is PP351, one of a series of the Plant Pathology Department, UF/IFAS Extension. Original publication date November 2019. Visit the EDIS website at https://edis.ifas.ufl.edu for the currently supported version of this publication.

2. Keevan MacKenzie, graduate research assistant, Plant Pathology Department; Jessica Chitwood, graduate research assistant, Horticultural Sciences Department; Gary Vallad, associate professor, Plant Pathology Department; and Sam Hutton, associate professor, Horticultural Sciences Department, UF/IFAS Gulf Coast Research and Education Center, Wimauma, FL 33598.

The Institute of Food and Agricultural Sciences (IFAS) is an Equal Opportunity Institution authorized to provide research, educational information and other services

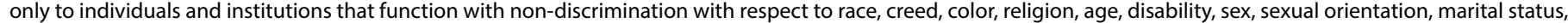

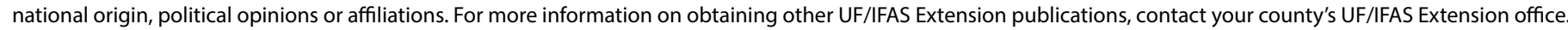
U.S. Department of Agriculture, UF/IFAS Extension Service, University of Florida, IFAS, Florida A \& M University Cooperative Extension Program, and Boards of County Commissioners Cooperating. Nick T. Place, dean for UF/IFAS Extension. 
a characteristic " $\mathrm{X}$ " or star-shaped cracking pattern on badly infested fruit. Fruit lesions often lead to postharvest fruit rots that can cause the rejection of commercial fruit shipments.

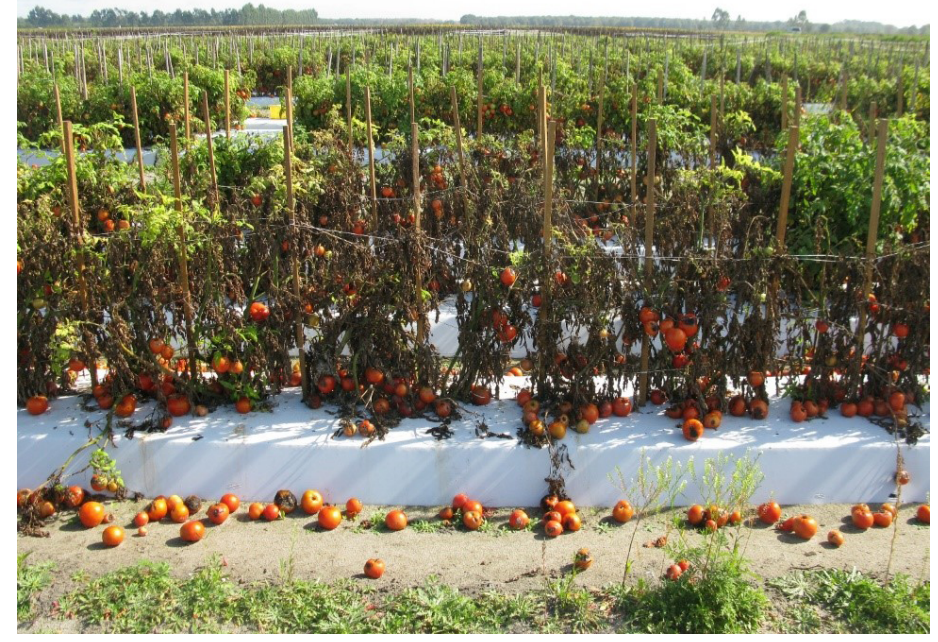

Figure 2. Excessive defoliation and fruit rot associated with target spot caused by Corynespora cassiicola.

Credits: G. Vallad, UF/IFAS

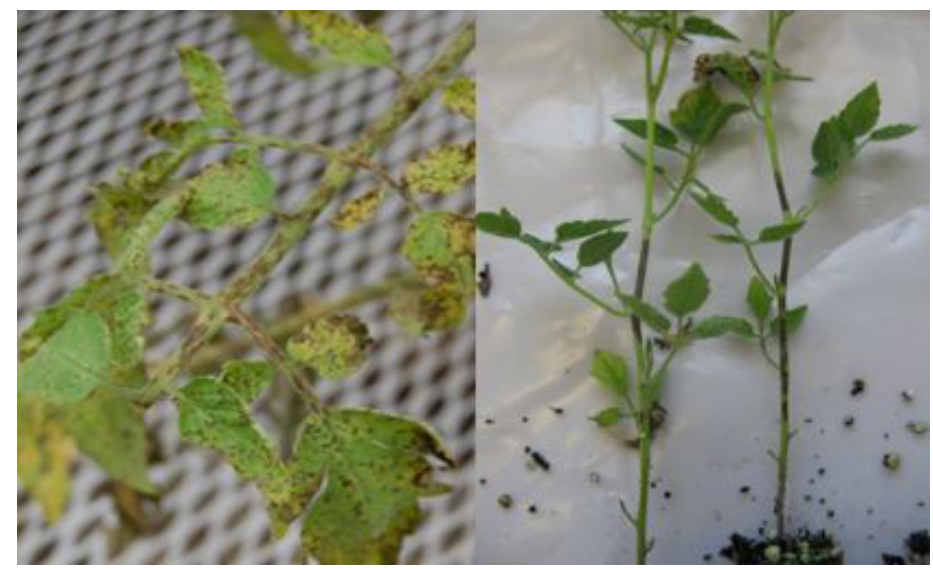

Figure 3. Tomato leaflets (left) and leaf petioles and stems (right) exhibiting symptoms of target spot caused by Corynespora cassiicola. Credits: K. MacKenzie, UF/IFAS

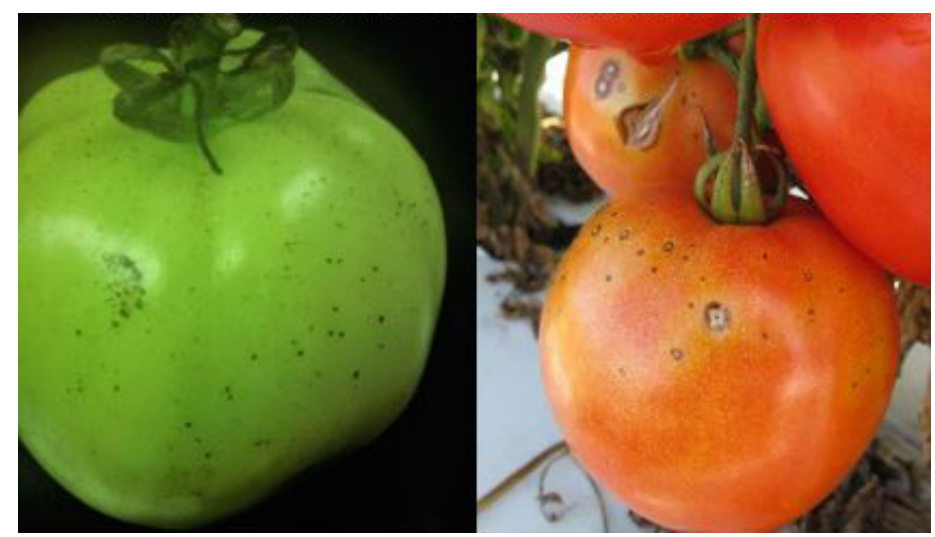

Figure 4. Tomato fruit exhibiting pinpoint and larger lesions typical of target spot caused by Corynespora cassiicola.

Credits: G. Vallad, UF/IFAS

\section{Epidemiology}

Once established, this pathogen produces asexual spores (conidia) throughout the season, which are disseminated by wind and rain (Figure 5). Target spot thrives in temperatures of $83^{\circ} \mathrm{F}-90^{\circ} \mathrm{F}$ with high humidity. Continuous leaf wetness is the most important factor for spores to germinate and infect the host (16-44 hrs).

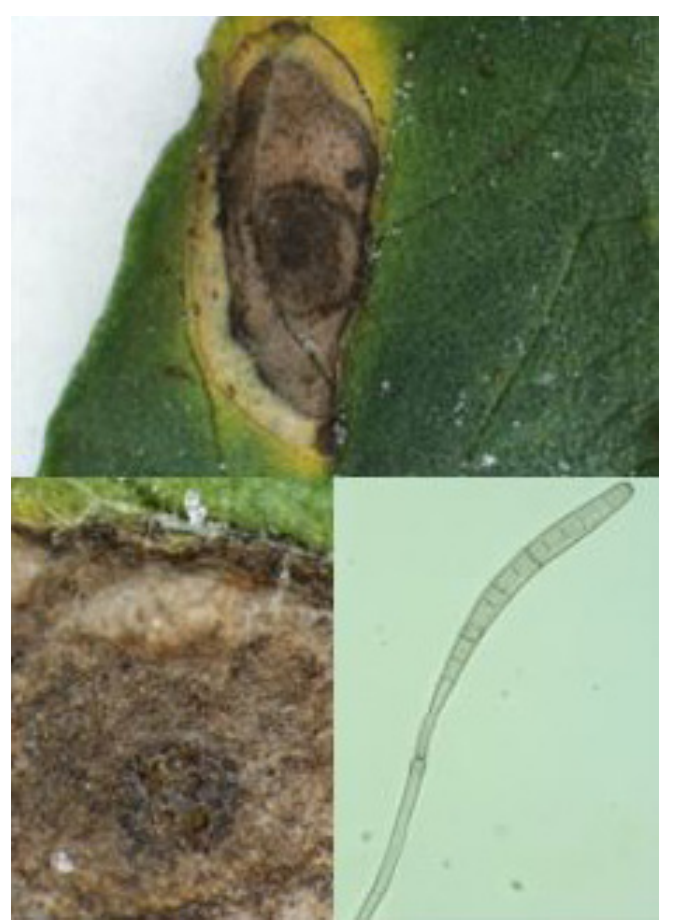

Figure 5. Typical foliar lesion of target spot on tomato caused by Corynespora cassiicola, with a close-up view of lesion showing sporulation (similar to view using a hand lens), and a view of spore (conidium) and spore-bearing structure (conidiophore) observed under a light microscope.

Credits: K. MacKenzie, UF/IFAS

Mature leaves are more susceptible than younger leaves, and fruits can be infected green or ripe. Target spot is especially problematic for seedlings as well as mature plants just before and after fruiting. As tomato plants grow larger, the canopy becomes dense and retains moisture for extended periods of time. It is common for disease to begin developing in the inner canopy and attack from the inside out (Figure 6). These interior infections often go undetected, allowing for rapid disease development. Fruit lesions will frequently develop on the side of the fruit facing the interior of the plant canopy (Figure 6).

Although target spot has been in Florida for over 40 years, outbreaks in the last 10 years have increased in frequency and severity. C. cassiicola has a very diverse host range and can depend on many alternative hosts for survival. In one study, the fungus was isolated from the infested tissues of 39 different plant species, including crops, ornamentals, and weeds. All isolates had some level of pathogenicity 
towards tomato (Dixon 2009). The pathogen has also been observed surviving on soybean debris for up to 2 years (Boosalis and Hamilton 1957).

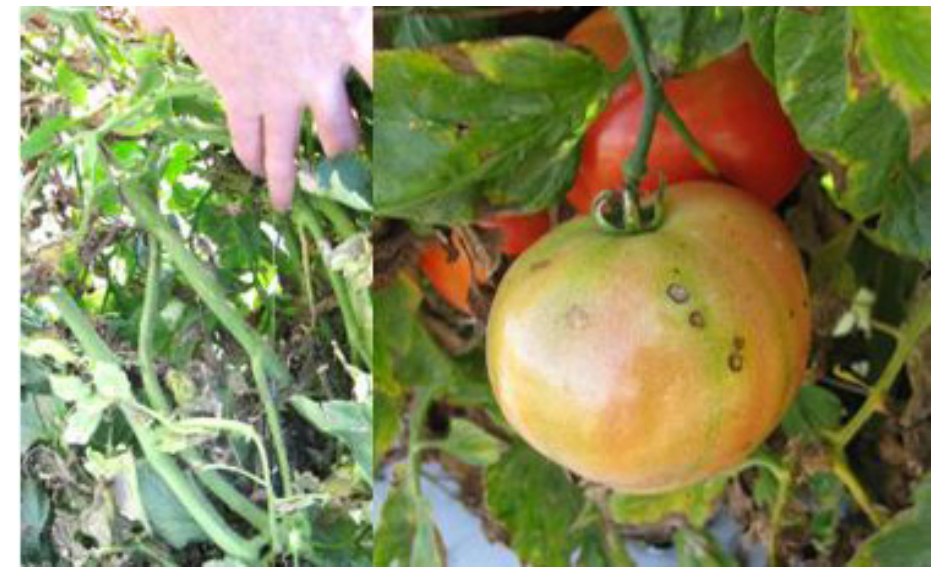

Figure 6. Pulling back outer tomato foliage to reveal defoliation caused by target spot within the interior canopy, and fruit with target spot lesions on the side of the fruit facing the canopy.

Credits: K. MacKenzie, UF/IFAS

In Florida, the time between growing seasons is short with moderate temperature fluctuations, which can facilitate the "over-seasoning" of many plant pathogens. It is hypothesized that the observed increase in disease incidence over the last decade may be associated with increased survival and carryover of the pathogen between seasons. Also, fungicide-resistant isolates may be harbored in diseased tissue and arise early the following season, making chemical control challenging.

One study found that C. cassiicola isolated from 4 different plant species developed survival structures (chlamydospores) in vitro (Oliveira et al. 2012) (Figure 7). Additional studies are necessary to better understand the importance of chlamydospores and environmental factors on the epidemiology of this disease.

\section{Breeding for Host Resistance}

There are currently no commercial tomato varieties available with resistance to target spot. Recent surveys of various commercial varieties suggest that although some varieties are more sensitive than others, these differences simply reflect degrees of susceptibility. Accessions of wild tomato species are commonly studied and used to introduce disease-resistance traits into modern varieties. However, two wild tomato accessions previously reported as tolerant to target spot back in 1972 (Bliss et al. 1973) were susceptible to recently collected isolates, suggesting a change in the pathogen population.

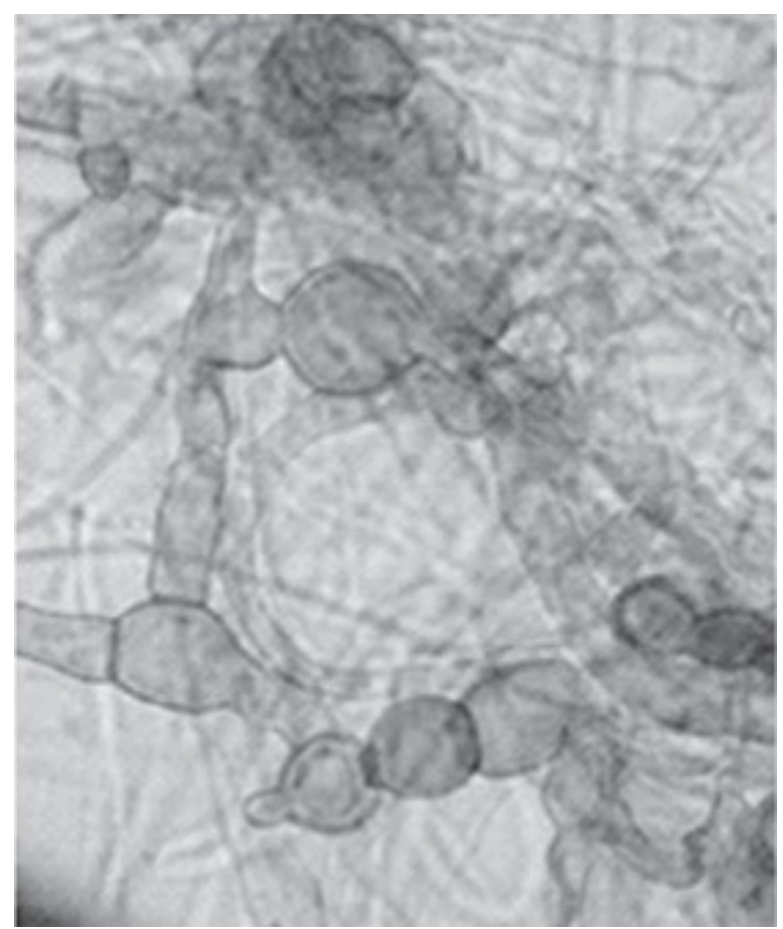

Figure 7. Microscopic image of chlamydospores that develop in cultures of Corynespora cassiicola. Chlamydospores are common structures produced by fungi that allow for prolonged survival in the environment. Additional research is necessary to address the exact role of chlamydospores for target spot of tomato.

Credits: K. MacKenzie, UF/IFAS

Current research efforts in the University of Florida tomato breeding and vegetable pathology programs at the UF/IFAS Gulf Coast Research and Education Center aim to identify new sources of resistance to target spot. Several promising accessions have been identified using seedling disease screens (Figure 8), and these accessions are currently being tested further to verify that resistance is effective in the field. Confirmed accessions will be used to introduce resistance genes from the wild accessions into cultivated tomato through traditional breeding methods. This can be a long and arduous process due to many undesirable traits from wild tomato species such as small fruit size, low yield, and late maturity that may be transferred along with traits of interest. Such problems can be compounded due to genetic barriers that prevent the crossing of cultivated tomato with some of its more distant relatives. Fortunately, all of the resistant accessions identified so far are species that readily cross with tomato, which will aid the breeding process. Regardless, several generations of breeding will still be required to produce resistant varieties that meet industry standards. 


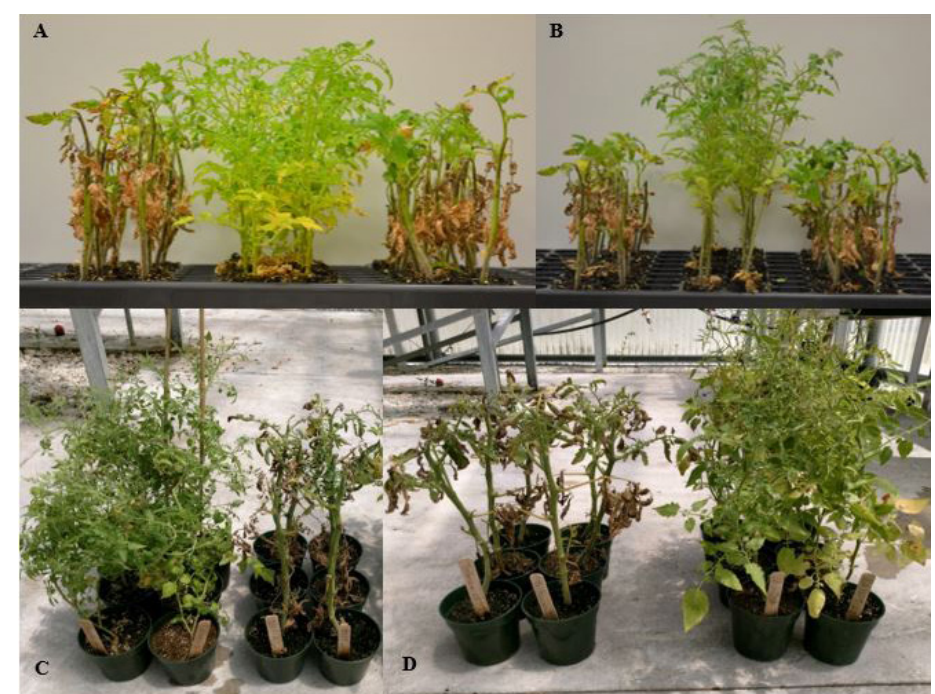

Figure 8. Responses of several wild tomato accessions relative to commercial controls upon inoculation with target spot. Sanibel (left) and Florida 47 are the susceptible controls in (A) and (B); Fla. 8059 in (C); and Tribeca in (D). Resistant accessions were identified in the wild tomato relatives, Solanum cheesmaniae (A and C) and Solanum pimpennellifolium (B and D).

Credits: J. Chitwood

\section{Integrated Management}

With no commercially available host resistance, the primary method to control target spot on tomato in Florida is with the routine application of protective fungicides (Figure 9). Without the use of fungicides on tomato in Florida, significant crop losses are to be expected. Conventional fungicides labelled for target spot on tomato can be found in the Vegetable Production Handbook of Florida (http:// edis.ifas.ufl.edu/topic_vph).

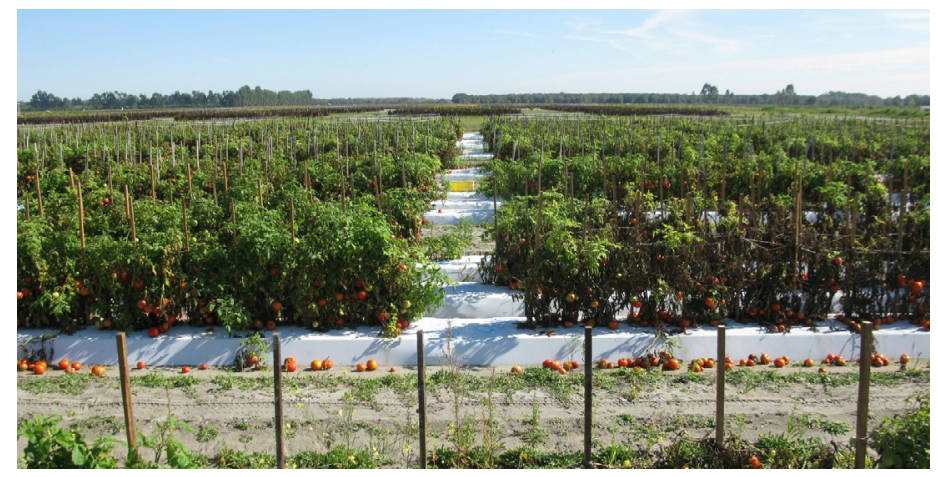

Figure 9. The benefit of preventative fungicides for the management of target spot on tomato, as shown in comparing the amount of defoliation and dropped fruit of plants treated with effective fungicides (left) versus the untreated control plants (right). Credits: G. Vallad, UF/IFAS

The handbook also includes a list of biopesticides and alternative disease-management products. However, field studies have shown that even with effective fungicides, the pathogen can still be difficult to control when environmental conditions favor rapid disease development.
Other cultural management strategies include rotating tomato fields with nonsolanaceous crops, starting with clean and healthy transplants, and eliminating weeds (especially Solanaceae family), volunteers, and plant debris that may harbor inoculum. Several studies have identified the production of chlamydospores by C. cassiicola in the field. Chlamydospores can serve as important survival structures for other pathogens, so further elucidation of their role for C. cassiicola survival could change target spot management strategies.

\section{Chemical Management}

The primary approach to managing target spot is through the timely use of effective fungicides. Many field studies have been conducted to analyze the effectiveness of different fungicides against target spot. As far back as 2001, reduced efficacy of the quinone outside inhibitor (QoI; FRAC 11) fungicide azoxystrobin had been reported (Pernezny 2002). Since then, in vitro studies, greenhouse experiments, and field trials have demonstrated variability in target spot control with QoI and succinate dehydrogenase inhibitor (SDHI; FRAC 7) fungicides (Vallad and Burlacu 2011; Vallad et al. 2016).

Recent field trials have shown several fungicides to be effective that include the following active ingredients (FRAC group): benzovindiflupyr (7), chlorothalonil (M5), cyprodinil (9), difenoconazole (3), fludioxonil (12), fluopyram (7), flutriafol (3), fluxapyroxad (7), mancozeb (M3), and pyrimethanil (9). The potential loss of SDHI (FRAC 7) fungicides due to fungicide resistance would seriously hamper management efforts, because respiration inhibitors (QoI and SDHI) make up a large portion of commercial fungicides labeled for target spot.

\section{References}

Blazquez, C. H. 1967. "Corynespora Leaf Spot of Cucumber." Proceedings of the Florida State Horticultural Society 80: 177-182.

Bliss, F. A., P. T. Onesirosan, and D. C. Arny. 1973. "Inheritance of Resistance in Tomato to Target Leaf Spot." Phytopathology 63: 837-840.

Boosalis, M. G., and R. I. Hamilton. 1957. "Root and Stem Rot of Soybean Caused by Corynespora cassiicola (Berk. \& Curt.) Wei." Plant Disease Reporter 41: 696-698.

Dixon, L. J., R. L. Schlub, K. Pernezny, and L. E. Datnoff. 2009. "Host Specialization and Phylogenetic Diversity of Corynespora cassiicola.” Phytopathology 99: 1015-1027. 
MacKenzie, K. J., L. G. Sumabat, K. V. Xavier, and G. E. Vallad. 2018. "A Review of Corynespora cassiicola and Its Increasing Relevance to Tomato in Florida." Plant Health Progress 19: 303-309.

McMillan, R. T. 1986. "Serious Diseases of Tropical Fruits in Florida." Proceedings of the Florida State Horticultural Society 99: 224-227.

NASS. 2018. Vegetables 2018 Summary, Census of Agriculture, United States Summary and State Data. United States Department of Agriculture, National Agricultural Statistics Service. March 2019.

Oliveira, R. R., B. D. M. Aguiar, D. J. Tessmann, V. PujadeRenaud, and J. B. Vida. 2012. "Chlamydospore Formation by Corynespora cassiicola." Tropical Plant Pathology 37: 415-418.

Onofre, R. B., J. C. Mertely, F. M. Aguiar, S. Timilsina, P. Harmon, G. E. Vallad, and N. A. Peres. 2016. "First Report of Target Spot Caused by Corynespora cassiicola on Blueberry in North America." Plant Disease 100: 528.

Pernezny, K., P. Stoffella, J. Collins, A. Carroll, and A. Beaney. 2002. "Control of Target Spot of Tomato with Fungicides, Systemic Acquired Resistance Activators, and a Biocontrol Agent." Plant Protection 38: 81-88.

Vallad, G. E., and V. Burlacu. 2011. "Initial Characterization of Corynespora cassiicola and Alternaria spp. Affecting Florida Tomatoes: Fungicide Resistance, Pathogen Variability, and Host Resistance." In Proceedings of the 2011 Florida Tomato Institute, edited by M. Ozores-Hampton and C. Snodgrass. 23-26. Naples, FL.

Vallad, G., K. MacKenzie, and H. Adkison. 2016. "Research Efforts to Improve Target Spot Management on Tomato." In Proceedings of the 2016 Florida Tomato Institute, edited by M. Ozores-Hampton and C. Snodgrass. 23-27. Naples, FL. 